\title{
Anti-inflammatory potential of ursolic acid in Mycobacterium tuberculosis-sensitized and Concanavalin A-stimulated cells
}

\author{
TAMANNA ZERIN $^{1 *}$, MINJUNG LEE ${ }^{1 *}$, WOONG SIK JANG ${ }^{2}$, KUNG-WOO NAM ${ }^{3}$ and HO-YEON SONG ${ }^{1}$ \\ ${ }^{1}$ Department of Microbiology, School of Medicine, Soonchunhyang University, Cheonan, Chungnam 330-090; \\ ${ }^{2}$ Regional Innovation Center; ${ }^{3}$ Department of Life Science and Biotechnology, College of Natural Science, \\ Soonchunhyang University, Asan, Chungnam 336-745, Republic of Korea
}

Received January 31, 2015; Accepted November 19, 2015

DOI: $10.3892 / \mathrm{mmr} .2016 .4840$

\begin{abstract}
Ursolic acid (3- $\beta$-3-hydroxy-urs-12-ene-28-oic-acid; $\mathrm{UA}$ ) is a triterpenoid carboxylic acid with various pharmaceutical properties. It is commonly found in apples, basil, berries, rosemary, peppermint, lavender, oregano, thyme, hawthorn and prunes. In the present study, the activities of UA against the Mycobacterium tuberculosis $\mathrm{H} 37 \mathrm{Rv}$-induced release of a panel of inflammatory cytokines, including tumor necrosis factor- $\alpha$ (TNF- $\alpha$ ), interleukin (IL)-1 $\beta$ and IL-6 from RAW 264.7 murine macrophages, A549 alveolar epithelial cells and in concanavalin A (Con A)-stimulated rat splenocytes were investigated. In addition, the present study examined the ability of UA to reduce the expression levels of the inflammatory mediators, cyclooxygenase-2 (COX-2) and inducible nitric oxide synthase (iNOS) in the stimulated cells. The reduction of nitric oxide (NO) release by UA was also examined in the stimulated cells. UA significantly inhibited the mRNA expression levels of $T N F-\alpha, I L-1 \beta$ and $I L-6$ in the stimulated cells. The expression levels of COX-2 and iNOS were also suppressed by UA, as was the release of $\mathrm{NO}$ at a significant level. The data indicated the potency of UA on different cell types, which may assist in the development of anti-inflammatory drugs. In the case of adjunct host-directed immune therapy for tuberculosis, UA may be used, in addition to established antibiotic therapies, to improve treatment efficacy and outcome due to their anti-inflammatory potential. Further detailed investigations are required to establish its use as an anti-inflammatory.
\end{abstract}

Correspondence to: Professor Ho-Yeon Song, Department of Microbiology, School of Medicine, Soonchunhyang University, 366-1 Ssangyoung-dong, Cheonan, Chungnam 330-090, Republic of Korea

E-mail: songmic@sch.ac.kr

*Contributed equally

Key words: ursolic acid, inflammatory cytokines, nitric oxide, Mycobacterium tuberculosis $\mathrm{H} 37 \mathrm{Rv}$, concanavalin A

\section{Introduction}

Inflammation is a complex biological response, acting as a self-defense mechanism against harmful environmental insults, which involves a network of cellular responses, cytokines, including interleukin (IL)-1 $\beta$, IL-6, tumor necrosis factor- $\alpha$ (TNF- $\alpha$ ), and humoral factors $(1,2)$. However, their persistence may lead to chronic inflammation, which may be associated with several diseases, including cancer $(1,3)$, neoplasia, inflammatory bowel disease, ulcerative colitis (4,5), arthritis (6), asthma and Alzheimer's disease (7). The detrimental effects of chronic inflammation can be controlled by conventional treatments, however, resistance to the drugs used and their side-effects necessitate the development of novel anti-inflammatory drugs (8). Previous studies have investigated the use of adjunct immunotherapies to improve treatment success for tuberculosis (TB). Among these, the immunosuppression-mediated reduction of TNF- $\alpha$ levels by current antibiotic therapies may eventually be effective in treating highly contagious TB (9).

In general, when $M$.tuberculosis enters the lung, it interacts with macrophages. Macrophages have been the most commonly examined cells in investigations of TB, although epithelial cells are being increasingly examined in TB, as they are essential in the immune response during pulmonary tuberculosis (10-13). Nitric oxide (NO) is an important mediator in cell signaling, neurotransmission and in the host defense mechanism $(14,15)$. M. tuberculosis infection induces the activity of inducible nitric oxide synthase (iNOS) in A549 cells, which leads to the production of a significant level of NO (13).

A natural triterpenoid carboxylic acid, 3- $\beta$-3-hydroxy-urs -12-ene-28-oic-acid (uracil; UA), is present in a wide variety of foods (16). Its biochemical and pharmacological effects include anti-inflammatory, antioxidant, antiproliferative, anticancer, antimutagenic, antihypertensive, and antiviral properties $(17,18)$. UA can also inhibit the immunoregulatory transcription factor, nuclear factor $\kappa$-light-chain-enhancer of activated $B$ cells $(\mathrm{NF}-\kappa \mathrm{B})$, in response to a wide variety of carcinogens and inflammatory agents (19). There is also evidence supporting the anti-inflammatory effects of UA (2).

In the present study, M. tuberculosis-induced RAW 264.7 mouse monocyte macrophages, A549 type II alveolar cells and 
mitogen, concanavalin A-induced rat splenocytes were used to examine the effect of UA on immune regulation. The aim of the present study was to investigate the anti-inflammatory potential of UA, a candidate drug for controlling inflammation-associated diseases.

\section{Materials and methods}

Cell culture. RAW 264.7 mouse monocyte macrophages and A549 type II alveolar cells, purchased from American Type Culture Collection (ATCC; Manassas, VA, USA) were maintained in Dulbecco's Modified Eagle's Medium (DMEM) supplemented with $10 \%$ heat-inactivated fetal bovine serum (FBS), $100 \mathrm{U} / \mathrm{ml}$ penicillin and $100 \mu \mathrm{g} / \mathrm{ml}$ streptomycin (Invitrogen; Thermo Fisher Scientific, Inc., Waltham, MA, USA) at $37^{\circ} \mathrm{C}$ in a humidified incubator with $5 \% \mathrm{CO}_{2}$ and sub-cultured every 2-3 days.

Reagents, treatment conditions and durations. The UA, $N^{\mathrm{G}}$-monomethyl-L-arginine (L-NMMA), and concanavalin A (Con A) were obtained from Sigma-Aldrich (St. Louis, MO, USA). Throughout the present study, the cells $\left(1 \times 10^{5}\right.$ cells $\left./ \mathrm{ml}\right)$ were treated with $10 \mu \mathrm{g} / \mathrm{ml} \mathrm{UA}$ and $5 \mathrm{mM} \mathrm{L-NMMA}$ for $6 \mathrm{~h}$ following $M$. tuberculosis infection, following which they were incubated for the specified durations. Immediately prior to infection or treatment, the medium were replaced with serum-free DMEM. In the case of the splenocytes, the cells $\left(1 \times 10^{6}\right.$ cells $\left./ \mathrm{ml}\right)$ were co-treated with $5 \mu \mathrm{g} / \mathrm{ml}$ Con A and $10 \mu \mathrm{g} / \mathrm{ml}$ UA for the specified durations.

Animals and primary splenocyte collection. Female Wistar rats (190-220 g; 8-weeks old; $\mathrm{n}=8$ ) were purchased from Nara Biotech, Ltd. (Pyeongtaek-si, Korea). The animals were housed in a solid-bottomed cage at $23 \pm 2^{\circ} \mathrm{C}$, maintained under a $12 \mathrm{~h}$ light-dark cycle and fed standard rodent chow (Purina Rodent Chow; Purina Co., Ltd., Seoul, Korea) and water ad libitum. The present study was performed according to the guidelines of the United States National Institutes of Health, and was approved by the ethics committee of Soonchunhyang University (Asan, Korea; SCH14-0031).

Primary splenocytes were collected from the rats following sacrifice by cervical dislocation, and aseptic collection of the spleen was performed. Each spleen was immersed in RPMI 1640 culture medium supplemented with 10\% (v/v) heat-inactivated FBS and a 1\% (v/v) antibiotic/antimycotic cocktail, comprising $100 \mathrm{U} / \mathrm{ml}$ penicillin, $100 \mu \mathrm{g} / \mathrm{ml}$ streptomycin and $0.25 \mu \mathrm{g} / \mathrm{ml}$ amphotericin B (Invitrogen; Thermo Fisher Scientific, Inc.). The cells were passed through a cell strainer (BD Biosciences, Durham, NC, USA) to form a single cell suspension. Erythrocytes were excluded from the resulting cell suspension using lysis buffer (Life Technologies, Seoul, Korea), containing $0.15 \mathrm{M} \mathrm{NH}_{4} \mathrm{Cl}, 10 \mathrm{mM} \mathrm{KHCO}_{3}$ and $0.1 \mathrm{mM} \mathrm{Na}{ }_{2}$ EDTA ( $\mathrm{pH}$ 7.3). The cells were washed once with phosphate-buffered saline (PBS) and cultured at a density of $10^{6}$ cells $/ \mathrm{ml}$. Cell viability was determined according to the exclusion of Trypan blue (Sigma-Aldrich). The cells were maintained under standard culture conditions at $37^{\circ} \mathrm{C}$.

Mycobacterium infection/invasion. The M. tuberculosis H37Rv strain was purchased from ATCC and was grown in
Middlebrook 7H11 agar (Becton Dickinson, Sparks, MD, USA) or Ogawa medium for $\sim 3$ weeks. Isolated colonies were inoculated in Middlebrook $7 \mathrm{H} 9$ broth (Becton Dickinson) in am incubator with agitation for 15 days. To avoid clumping, the bacterial suspension was vortexed vigorously with glass beads, and then passed through an $8-\mu \mathrm{m}$ filter to form a single cell suspension. The suspension was allowed to stand for several minutes to settle and two-thirds of the clear upper portion of suspension was used for quantification at $600 \mathrm{~nm}$ using the UVmini-1240 spectrophotometer (Shimadzu, Kyoto, Japan) adjusted with McFarland standards. A $0.5 \mathrm{McF}$ arland standard was prepared by mixing $0.05 \mathrm{ml}$ of $1.175 \%$ barium chloride dihydrate with $9.95 \mathrm{ml}$ of $1 \%$ sulfuric acid. Subsequently, $10 \mu \mathrm{l}$ of the suspension was inoculated in Middlebrook $7 \mathrm{H} 11$ agar or Ogawa medium at $37^{\circ} \mathrm{C}$ in an atmosphere of $5 \% \mathrm{CO}_{2}$ for 3-4 weeks to quantify the bacterial number in colony forming units (cfu). Following count determination, the bacterial suspension was aliquoted and stored at $-76^{\circ} \mathrm{C}$ as a single volume

For in vitro infection, the RAW 264.7 ( $2 \times 10^{5}$ cells) and A549 ( $2 \times 10^{5}$ cells) cells we re grown in six-well plates overnight and infected with $M$.tuberculosis $\mathrm{H} 37 \mathrm{Rv}$ at a 1:10 ratio for $3 \mathrm{~h}$ in the aforementioned cell culture conditions. The cells were washed with warm PBS three to five times to remove extracellular bacteria. To confirm successful invasion of the bacteria, the final wash medium and cell extract $(100 \mu \mathrm{l})$, following cell dissolution with $0.1 \%$ Triton X-100 (Sigma-Aldrich), were inoculated in Middlebrook 7H11 agar for colony counting, Middlebrook $7 \mathrm{H} 9$ broth for a resazurin assay (20) and in a Bactec MGIT system (Becton Dickinson) for the determination of time to detection (TTD) (21), as described previously (22). Prior to proceeding, it was confirmed that the bacteria present in the final wash medium were absent or few in number, compared with the high numbers of viable bacteria in the extracted cell suspension, which confirmed successful bacterial invasion.

Cell viability assay. The cell viability assay performed in the present study was based on the conversion of 3-(4,5-dimethylthiazol-2-yl)-2,5-diphenyltetrazolium bromide (MTT; Sigma-Aldrich) to formazan crystals by the mitochondrial dehydrogenase enzyme (23). In brief, the cells ( $1 \times 10^{5}$ cells $\left./ \mathrm{ml}\right)$ were seeded overnight to achieve $\sim 80 \%$ confluence and were treated with $10 \mu \mathrm{g} / \mathrm{ml} \mathrm{UA}$ for $0,6,12,24,48$ and $72 \mathrm{~h}$. At the determined time, $20 \mu \mathrm{l}$ of $5 \mathrm{mg} / \mathrm{ml} \mathrm{MTT}$ reagent was added. Following $4 \mathrm{~h}$ incubation at $37^{\circ} \mathrm{C}$, the medium were aspirated, and $100 \mu \mathrm{l}$ of dimethylsulfoxide (Samchun Pure Chemical Co., Ltd., Pyeongtaek, Korea) was added to dissolve the formazan crystals. The absorbance was measured at $570 \mathrm{~nm}$ using a Victor $^{\mathrm{TM}} \mathrm{X} 3$ multilabel reader (Perkin Elmer, Inc., Waltham, MA, USA).

Splenocyte viability was determined using an MTS-based assay (24). In brief, the cells were treated for the indicated times periods, and the detection reagent was prepared using MTS and phenazine methosulfate (Sigma-Aldrich) at a ratio of 20:1, which was added at a 1:5 ratio of reagent mixture to cell culture. The absorbance was detected at $492 \mathrm{~nm}$ using the Victor $^{\mathrm{TM}} \mathrm{X} 3$ multilabel reader.

$R N A$ extraction and reverse transcription-quantitative polymerase chain reaction ( $R T-q P C R)$. The cells were infected 
Table I. List of primers used for reverse transcription-quantitative polymerase chain reaction analysis.

\begin{tabular}{|c|c|c|}
\hline Gene & Forward primer $\left(5^{\prime} \rightarrow 3^{\prime}\right)$ & Reverse primer $\left(5^{\prime} \rightarrow 3^{\prime}\right)$ \\
\hline \multicolumn{3}{|l|}{ Mouse } \\
\hline$T N F-\alpha$ & TGTCTCAGCCTCTTCTCATT & AGATGATCTGAGTGTGAGGG \\
\hline$I L-6$ & TTGCCTTCTTGGGACTGATG & CCACGATTTCCCAGAGAACA \\
\hline$I L-1 \beta$ & GGGCTGCTTCCAAACCTTTG & TGATACTGCCTGCCTGAAGCTC \\
\hline$i N O S$ & CССTTCCGAAGTTTCTGGCAGCAGC & GGCTGTCAGAGCCTCGTGGCTTTGG \\
\hline$C O X-2$ & CCAGCACTTCACCCATCAGTT & ACCCAGGTCCTCGCTTATGA \\
\hline L32 & GCCAGGAGACGACAAAAAT & ААТССТСТTGCССТGATCC \\
\hline \multicolumn{3}{|l|}{ Human } \\
\hline$T N F-\alpha$ & TCTTCTCGAACCCCGAGTGA & CCTCTGATGGCACCACCAG \\
\hline iNOS & CCTCTGATGGCACCACCAG & ACCCTGCCAACGTGGAATTCACTCAG \\
\hline$C O X-2$ & TTCAAATGAGATTGTGGGAAAATTGCT & AGATCATCTCTGCCTGAGTATCTT \\
\hline GAPDH & TCССАТСАССАТСТТССА & CATCACGCCACAGTTTCC \\
\hline \multicolumn{3}{|l|}{ Rat } \\
\hline$T N F-\alpha$ & GACCCTCACACTCAGATCATCTTCT & TGCTACGACGTGGGCTACG \\
\hline$I L-6$ & CGAGCCCACCAGGAACGAAAGTC & CTGGCTGGAAGTCTCTTGCGGAG \\
\hline$I L-1 \beta$ & CCCTGCAGCTGGAGAGTGTGG & TGTGCTCTGCTTGAGAGGTGCT \\
\hline$i N O S$ & GTGCTAATGCGGAAGGTCATG & GCTTCCGACTTTCCTGTCTCAGTA \\
\hline$C O X-2$ & GTGTCCCTTTGCCTCTTTCAAT & GAGGCACTTGCGTTGATGGT \\
\hline$G A P D H$ & ATGATTCTACCCACGGCAAG & CTGGAAGATGGTGATGGGTT \\
\hline
\end{tabular}

TNF- $\alpha$, tumor necrosis factor- $\alpha$; IL, interleukin; iNOS, inducible nitric oxide synthase; COX-2, cyclooxygenase-2; GAPDH, glyceraldehyde 3-phosphate dehydrogenase.

and/or treated for the indicated time periods, following which the total RNA was extracted using an RNeasy Mini kit (Qiagen, Valencia, CA, USA) and quantified using an ND-1000 spectrophotometer (NanoDrop Technologies, Wilmington, NC, USA) at $260 \mathrm{~nm}$. The assay used RNA at a 260:280 nm ratio of 1.8-2.0, indicating high purity. Subsequently, cDNA was prepared using 1,000 ng of the total RNA using Oligo $\mathrm{dT}_{15}$ Primer (Maxime ${ }^{\mathrm{TM}}$ RT PreMix kit; Intron Biotechnology, Inc., Seongnam, Korea) in a Veriti ${ }^{\circledR}$ 96-Well Thermal Cycler (Applied Biosystems; Thermo Fisher Scientific, Inc.). Subsequently, qPCR was performed to amplify the cDNA using an iQ SYBR Green Supermix kit (Bio-Rad Laboratories, Inc., Hercules, CA, USA), according to the manufacturer's protocol, in a CFX96TM real-time PCR detection system (Bio-Rad Laboratories, Inc.). The temperature cycle followed for qPCR was as follows: $95^{\circ} \mathrm{C}$ for $5 \mathrm{~min}$, followed by 40 cycles of $95^{\circ} \mathrm{C}$ for $10 \mathrm{sec}, 42^{\circ} \mathrm{C}$ for $10 \mathrm{sec}$ and $72^{\circ} \mathrm{C}$ for $20 \mathrm{sec}$. A dissociation curve was acquired to ensure the specificity of the PCR product in every PCR assay. The assay results were normalized to the endogenous control gene, glyceraldehyde 3-phosphate dehydrogenase. The primers used were purchased from Bioneer Corporation (Seoul, Korea) and are listed in Table I, with the exception of human interleukin $1-\beta(I L-1 \beta)$, and interleukin 6 (IL-6), which were also purchased from Bioneer Corporation (Seoul, Korea; cat. nos. N-1058 and N-1063, respectively). Relative quantification was obtained using the comparative threshold cycle $(\Delta \Delta \mathrm{Cq})$ method. A CFX96 ${ }^{\mathrm{TM}}$ real-time PCR detection system (Bio-Rad Laboratories, Inc.) with a default calculation system was used.
NO release assay. NO release was measured by detecting the concentration of nitrite produced, using the Griess reagent system (Promega Corporation, Madison, WI, USA). Briefly, nitrite standards were prepared, ranging between 100 and $1.56 \mu \mathrm{M}(100,50,25,12.5,6.25,3.13$ and $1.56 \mu \mathrm{M})$ by serial 2 -fold dilutions. The cell-free supernatants were obtained by centrifugation at $2,000 \mathrm{x} \mathrm{g}$ for $1 \mathrm{~min}$ at room temperature. The nitrite standards and cell-free supernatants from the infected and/or treated samples $(50 \mu \mathrm{l})$ were added to a 96-well tissue culture plate in triplicate. Subsequently, $50 \mu 1$ sulphanilamide solution was added to each well, and incubated for $10 \mathrm{~min}$ at room temperature in the dark, followed by the addition of $50 \mu 1 \mathrm{~N}-1$-napthylethylenediamine dihydrochloride. The absorbance was measured at $540 \mathrm{~nm}$ using the Victor ${ }^{\mathrm{TM}}$ X3 multilabel reader.

Statistical analysis. Data are presented as the mean \pm standard deviation. At least three individual experiments were performed. Statistical analyses were performed using SPSS 17.0 (SPSS, Inc., Chicago, IL, USA), Differences between groups were analyzed using one-way analysis of variance, followed by the Student's t-test. $\mathrm{P}<0.05$ was considered to indicate a statistically significant difference.

\section{Results}

Effect of UA on cell viability. Prior to the experiments, it was necessary to evaluate the effect of UA on cell viability. Cell viability was determined using an MTT assay for the RAW 
A

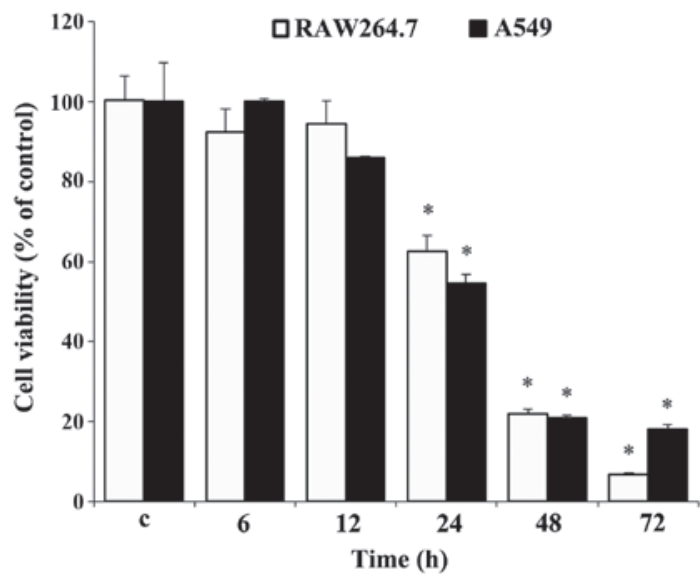

B

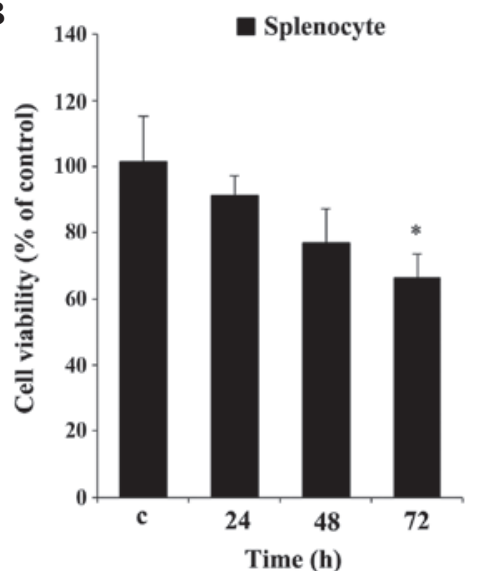

Figure 1. Effect of UA on cell viability using a 3-(4,5-dimethylthiazol-2-yl)-2,5-diphenyltetrazolium bromide assay. (A) RAW 264.7 and A549 cells were treated with $10 \mu \mathrm{g} / \mathrm{ml} \mathrm{UA}$ for 6-72 $\mathrm{h}$ and (B) rat splenocytes were treated with similar doses of UA for 24-72 h. Data are presented as the mean \pm standard deviation of three independent experiments. ${ }^{*} \mathrm{P}<0.05$, vs. control; UA, ursolic acid; c, control.

264.7 and A549 cells (Fig. 1A), and using an MTS assay for the rat splenocytes (Fig. 1B). Measurements over time established that significant cytotoxicity was evident, beginning at $24 \mathrm{~h}$, in the two cell lines. At $72 \mathrm{~h}, 10 \mu \mathrm{g} / \mathrm{ml}$ UA resulted in cytotoxicity towards the RAW 264.7 cells, which was almost $11 \%$ higher than that in the A549 cells (Fig. 1A). By contrast, the splenocytes showed less cytotoxicity under similar treatment conditions between 24 and 72 h, compared with the RAW 264.7 and A549 cells. No significant difference in splenocyte viability was found at any time point, with the exception of $72 \mathrm{~h}$ (Fig. 1B), at which the cell viability was decreased by almost 35\%, which was marginal, compared with the other two cell types at $72 \mathrm{~h}$ (Fig. 1B).

UA suppresses infection- and Con A-induced cytokine expression. Cytokines are critical in the development and regulation of immune responses. Several phytochemicals are involved in the immunomodulatory activities of the immune system and, thus, are key in immunosuppression. The expression levels of genes encoding $T N F-\alpha, I L-6$ and $I L 1-\beta$ in different cells was evaluated following infection and/or treatment. The M. tuberculosis-infected RAW 264.7 cells showed a significant induction of the mRNA expression of TNF- $\alpha$ at 12 and $24 \mathrm{~h}$ (Fig. 2A). This induction was significantly reduced by treatment of the RAW 264.7 cells with UA. In the A549 cells, the induction of $T N F-\alpha$ by infection, and the reduction by UA were not significant (Fig. 2B). UA treatment alone reduced the mNRA levels of $T N F-\alpha$ in the RAW 264.7 cells at $12 \mathrm{~h}$, however, the expression returned to a basal level at $24 \mathrm{~h}$. In the A549 cells, UA did not induce significant changes at any time point (Fig. 2A and B). In the splenocytes, the Con A mitogen was used to investigate the immunoregulatory activity of UA. Con A increased the mRNA expression of $T N F-\alpha$ by $\sim 2$-fold at $12 \mathrm{~h}$, which increased to 3 -fold at $24 \mathrm{~h}$. At both time points, UA significantly reduced the mRNA expression levels ofTNF- $\alpha$, compared with the control (Fig. 2C).

IL-6 acts as pro-inflammatory, as well as an anti-inflammatory, cytokine. In the RAW 264.7 cells, infection induced the mRNA expression of $I L-6$ at $24 \mathrm{~h}$, and was significantly reduced by UA treatment. Of note, the reduction was even lower than the basal level. Treatment with UA alone had no significant effect on the mRNA expression of $I L-6$ (Fig. 3A). In the A549 cells, infection and/or treatment showed no significant change at $12 \mathrm{~h}$, however, at $24 \mathrm{~h}$ the mRNA expression of $I L-6$ increased almost 5-fold. UA significantly reduced this induced expression (Fig. 3B). No significant changes in the mRNA expression of $I L-6$ mRNA were observed in the Con A and/or UA-treated splenocytes at $12 \mathrm{~h}$. However, at $24 \mathrm{~h}$, the expression of $I L-6$ was significantly induced when treated with Con A, and UA successfully reduced this induced expression (Fig. 3C).

IL-1 $\beta$ is a pro-inflammatory cytokine, which was found to be significantly induced by $M$. tuberculosis $\mathrm{H} 37 \mathrm{Rv}$ infection in RAW 264.7 cells (Fig. 4A) and A549 cells (Fig. 4B) at 12 and $24 \mathrm{~h}$. Their induction was effectively reduced by UA treatment, however, in the RAW 264.7 cells, the reduction was below the basal level at $12 \mathrm{~h}$, compared with the control (Fig. 4A and B). Compared with the RAW 264.7 and A549 cells, no significant changes were observed in the splenocytes treated with Con A and/or UA at $12 \mathrm{~h}$. However, at $24 \mathrm{~h}$, Con A induced the expression of $I L-1 \beta$, whereas UA had no significant effect (Fig. 4C).

Infection- and Con A-induced expression of iNOS and COX-2 expression is regulated by UA. The $i N O S$ and $C O X-2$ genes are usually induced by inflammation. To evaluate the effect of UA on their expression levels, the present study infected RAW 264.7 cells with $M$. tuberculosis H37Rv and/or treated the cells with UA. Infection induced the expression of the two genes significantly at 12 and $24 \mathrm{~h}$. These levels of expression were significantly suppressed by UA at both time points. The gene expression of $i N O S$ and $C O X-2$ were suppressed below the basal level at $24 \mathrm{~h}$. No significant changes in the gene expression of $i N O S$ or $C O X-2$ were observed in the cells treated with UA only (Fig. 5A and B).

The inflammatory response was induced in the splenocytes by treatment with the Con A mitogen. At $24 \mathrm{~h}$, the expression of the $i N O S$ gene was induced almost 5-fold, compared with the control, however, UA suppressed the expression by $\sim 2$-fold. No significant changes in the expression of $i N O S$ were 
A

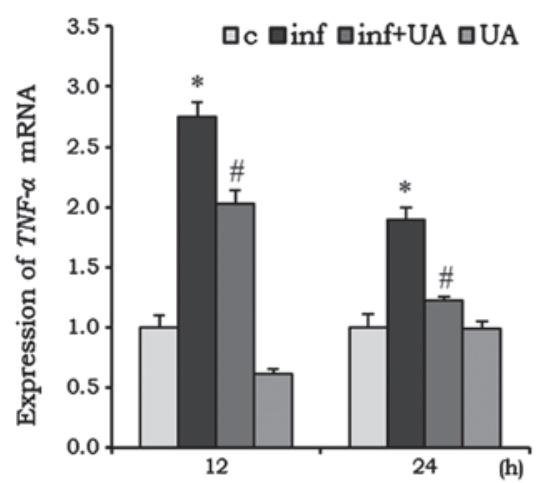

B

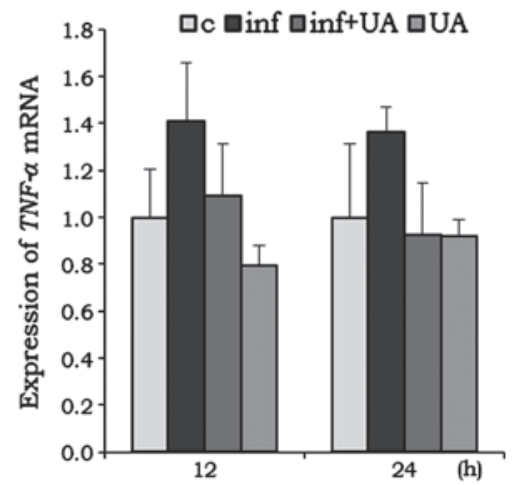

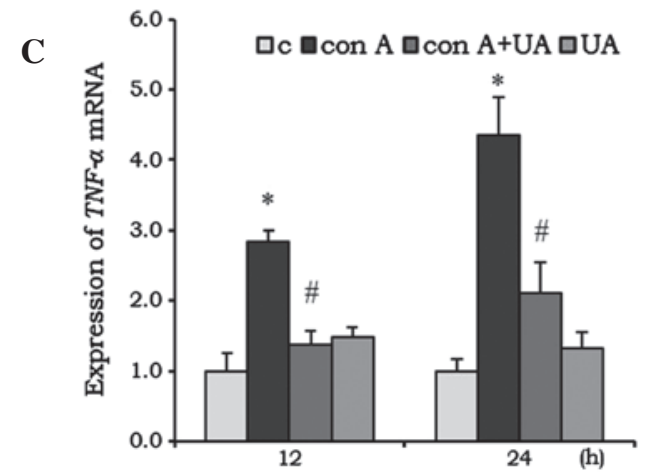

Figure 2. UA has an inhibitory effect on the expression of TNF- $\alpha$. (A) RAW 264.7 cells and (B) A549 cells were infected with M.tuberculosis H37Rv (1:10) for $3 \mathrm{~h}$ and $/$ or treated with $10 \mu \mathrm{g} / \mathrm{ml}$ UA for $6 \mathrm{~h}$. (C) Rat splenocytes were co-treated with $5 \mu \mathrm{g} / \mathrm{ml}$ Con A and $/ o r ~ 10 \mu \mathrm{g} / \mathrm{ml} \mathrm{UA}$. Following 12 and $24 \mathrm{~h}$ treatment, the cells were harvested for total RNA collection, cDNA preparation and reverse transcription-quantitative polymerase chain reaction analysis. Data is presented as the mean \pm standard deviation of three independent experiments. ${ }^{*} \mathrm{P}<0.05$, vs. control; ${ }^{~} \mathrm{P}<0.05$, inf $+\mathrm{UA}$, vs. inf or Con $\mathrm{A}$. TNF- $\alpha$, tumor necrosis factor- $\alpha$; c, control; inf, infection; UA, ursolic acid; Con A, concanavalin A.

A
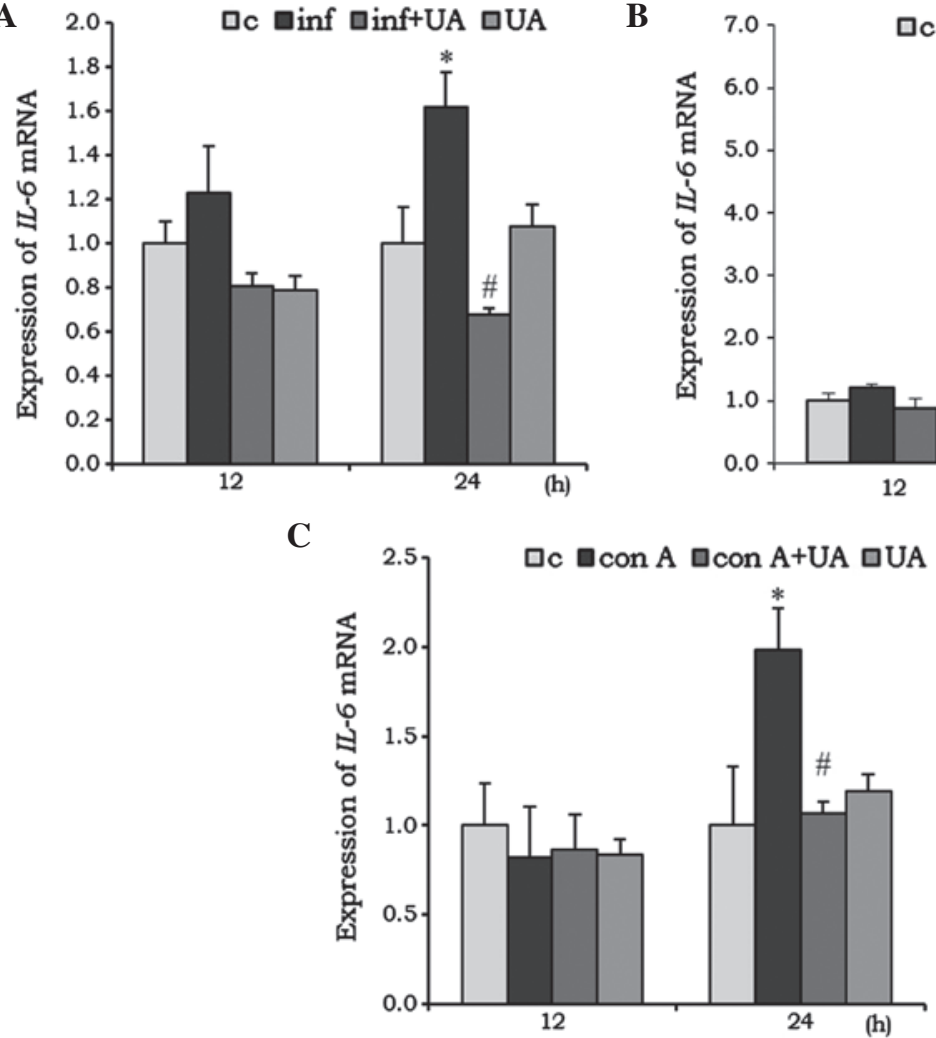

Figure 3. UA has an inhibitory effect on the expression of $I L-6$ in RAW 264.7 cells, A549 cells and rat splenocytes. (A) RAW 264.7 cells and (B) A549 cells were infected with $M$. tuberculosis $\mathrm{H} 37 \mathrm{Rv}$ for $3 \mathrm{~h}$ and/or treated with $10 \mu \mathrm{g} / \mathrm{ml} \mathrm{UA}$ for $6 \mathrm{~h}$. (C) Rat splenocytes were treated with $5 \mu \mathrm{g} / \mathrm{ml} \mathrm{Con} \mathrm{A} \mathrm{and/or}$ $10 \mu \mathrm{g} / \mathrm{ml}$ UA. Following 12 and $24 \mathrm{~h}$ of incubation, the cells were harvested for total RNA collection, cDNA preparation and reverse transcription-quantitative polymerase chain reaction analysis of $I L-6 \mathrm{mRNA}$. Data is presented as the mean \pm standard deviation of three independent experiment. " $\mathrm{P}<0.05$, vs, control; ${ }^{\#} \mathrm{P}<0.05$, inf+UA, vs. inf or Con A. IL, interleukin; c, control; inf, infection; UA, ursolic acid; Con A, concanavalin A. 
A

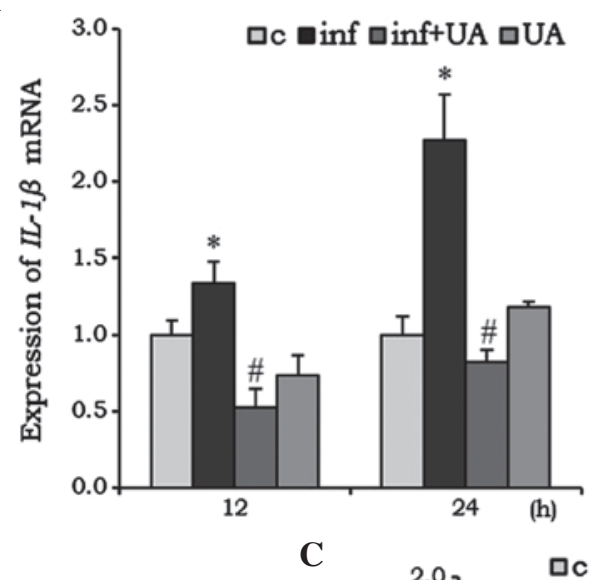

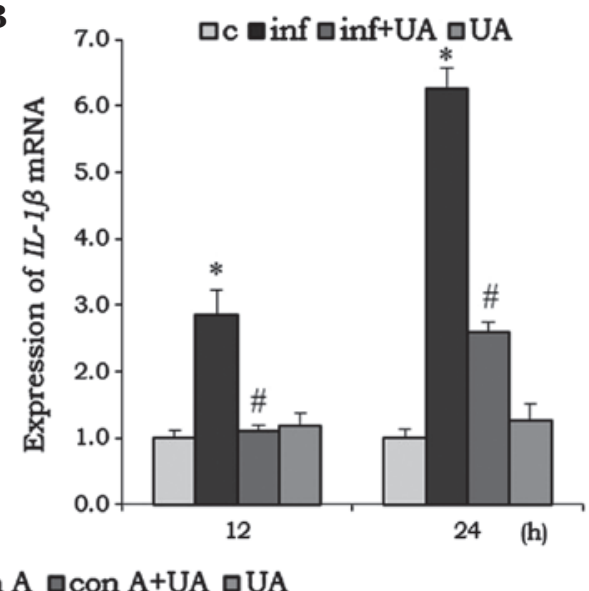

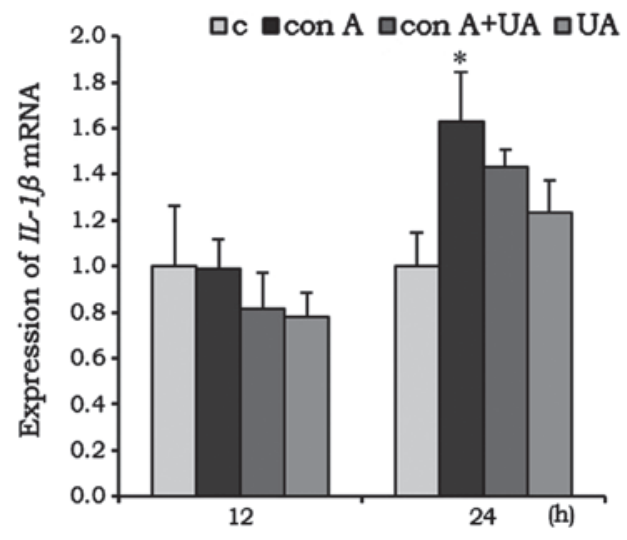

Figure 4. Effect of UA on the mRNA expression of $I L-1 \beta$. (A) RAW 264.7 cells, (B) A549 cells were infected and/or treated with UA, and (C) rat splenocytes were infected and/or treated with Con A. Following indicated period of incubation, the cells were harvested for total RNA collection, cDNA preparation and reverse transcription-quantitative polymerase chain reaction analysis for $I L-1 \beta$. Data is presented as the mean \pm standard deviation of three independent experiments " $\mathrm{P}<0.05$, vs. control; ${ }^{\text {}} \mathrm{P}<0.05$ vs. Inf or Con A. IL, interleukin; c, control; inf, infection; UA, ursolic acid; Con A, concanavalin A.

evident at $12 \mathrm{~h}$ in the samples treated with Con A and/or UA (Fig. 5C). However, at 12 and $24 \mathrm{~h}$, the expression of $C O X-2$ was induced significantly by Con A treatment. UA treatment reduced this induced expression significantly at $24 \mathrm{~h}$, but not at $12 \mathrm{~h}$ (Fig. 5D). Treatment of the splenocytes with UA alone did not significantly alter the gene expression levels of $i N O S$ or $C O X-2$ from the basal level (Fig. 5C and D).

UA suppresses NO release in RAW 264.7 and A549 cells. NO is a signaling molecule, which is important in modulating the release of various inflammatory mediators from a wide range of cells (25). Infection of RAW 264.7 (Fig. 6A) and A549 (Fig. 6B) cells with M. tuberculosis H37Rv produced a significant release of NO into the culture medium at 24 and $48 \mathrm{~h}$, respectively. The alveolar epithelial A549 cells did not appear to release NO prior to $48 \mathrm{~h}$. In addition, treatment with UA or the NO synthase inhibitor significantly reduced the release of NO in the two cell types at these time points. Of note, UA and the NO synthase inhibitor also induced NO release in the two cell type, although without statistical significance (Fig. 6A and B).

\section{Discussion}

Inflammation is a healing process in the body, however, when it is prolonged, various diseases can result (26). Immunomodulatory therapy of $\mathrm{TB}$ reduces excessive inflammation and restricts pathology. Pro- and anti-inflammatory drugs may have significant potential in tailoring TB treatment, when administered with routine anti-TB drugs (27-29). In the present study, M. tuberculosis H37Rv was selected to infect mouse monocyte macrophages, RAW 264.7 and A549 type II alveolar cells. In the majority of previous studies, alveolar macrophages were considered for TB-associated studies. Alveolar epithelial cells are now also considered to be involved in pathogenesis and in the innate immune response $(30,31)$. Natural compounds are a valuable source for a wide array of prospective biomedical uses, due to their limited side effects. UA shows anti-inflammatory potential in RAW 264.7 cells by attenuating the expression of iNOS and COX-2 $(32,33)$. The anti-inflammatory potential of UA has also been reported in activated T cells, B cells and macrophages (34). The mechanism underlying these effects has been attributed to the inhibition of mitogen-induced phosphorylation of extracellular signal-regulated kinase and c-Jun, $\mathrm{N}$-terminal kinase, and the suppression of immunoregulatory transcription factors, NF- $\mathrm{NB}$ and nuclear factor of activated $\mathrm{T}$ cells and activator protein-1. Notably, UA mitigates lipopolysaccharide-induced expression of TNF- $\alpha$, IL- $1 \beta$ and IL- 6 in splenic adherent macrophages (34). In the present study, UA was investigated for its potential anti-inflammatory activity in differentially stimulated cells. A comparative investigation was performed to determine the gene expression levels of the $T N F-\alpha, I L-1 \beta$ and $I L-6$ cytokines, the $i N O S$ and $C O X-2$ 
A

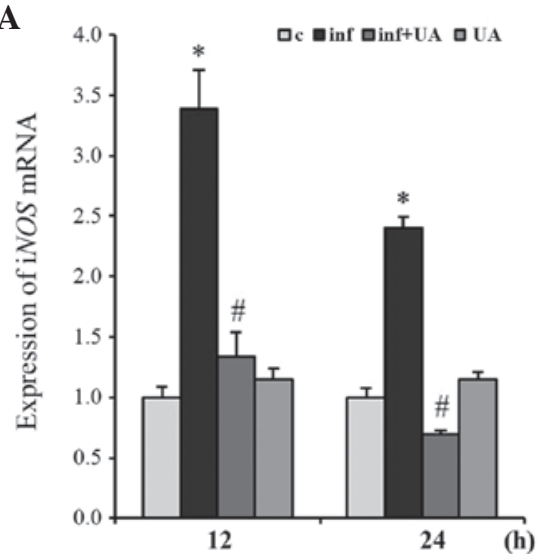

C

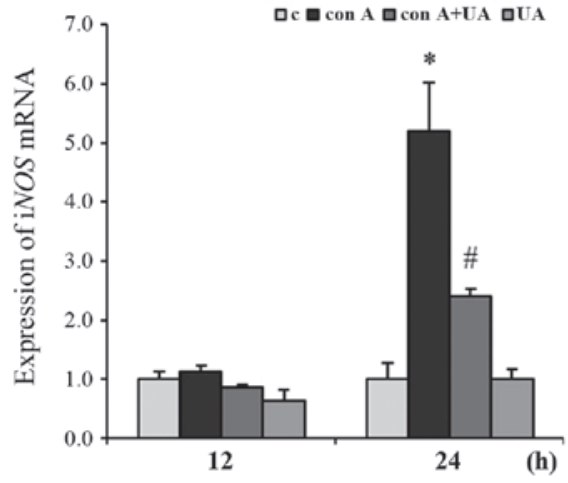

$\mathbf{B}$

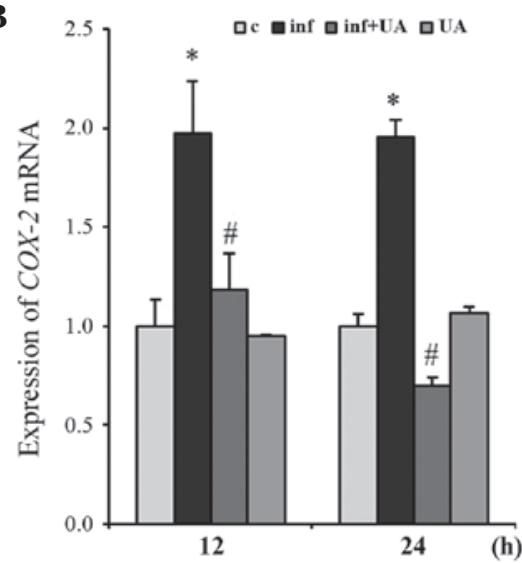

D

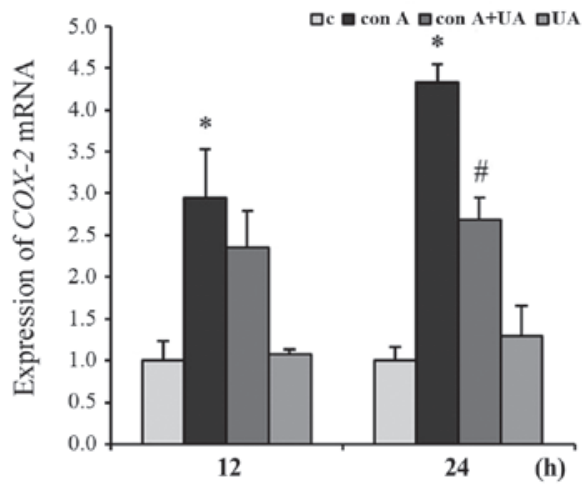

Figure 5. UA suppresses the expression of the iNOS and COX-2 inflammatory mediators. (A and B) RAW 264.7 cells were infected and/or treated with UA. (C and D) rat splenocytes were treated with con A and/or UA. Following incubation, the cells were harvested, total RNA was collected, cDNA was prepared and reverse transcription-quantitative polymerase chain reaction analysis was performed for $i N O S$ and $C O X-2$. Data is presented as the mean \pm standard deviation of three independent experiments " $\mathrm{P}<0.05$, vs. control; ${ }^{*} \mathrm{P}<0.05$, vs. inf or Con A. iNOS, inducible nitric oxide synthase; COX-2, cyclooxygenase-2; c, control; inf, infection; UA, ursolic acid; Con A, concanavalin A.

A

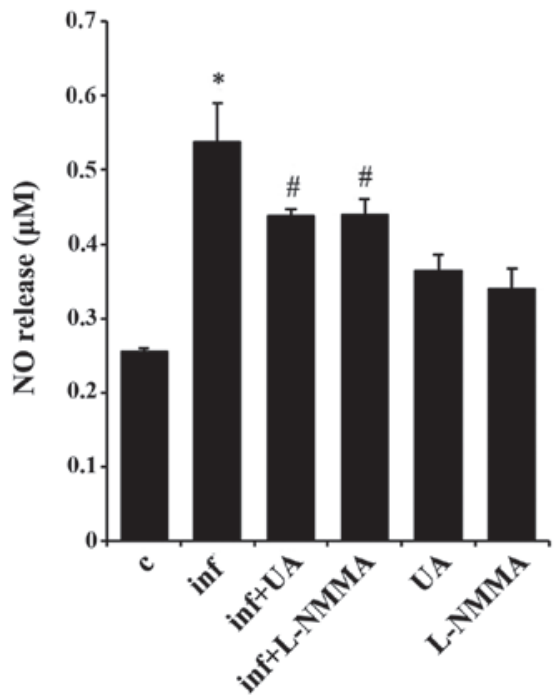

B

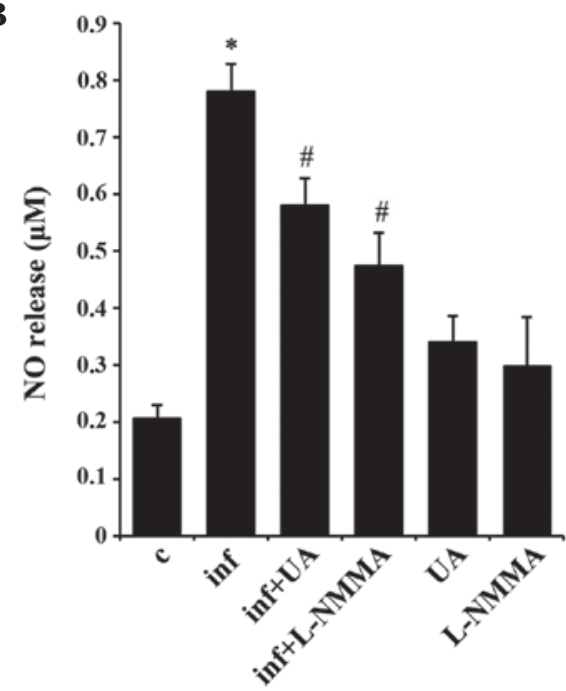

Figure 6. UA inhibits NO release. M. tuberculosis H37Rv infected (A) RAW 264.7 cells and (B) A549 (B) cells were treated with UA or L-NMMA for $6 \mathrm{~h}$, or left untreated, and incubated for 24 and $48 \mathrm{~h}$, respectively. Data is presented as the mean \pm standard deviation of three independent experiments. ${ }^{*} \mathrm{P}<0.05$, vs. control; " $\mathrm{P}<0.05$, vs. inf. NO, nitric oxide; L-NMMA, $\mathrm{N}^{\mathrm{G}}$-monomethyl-L-arginine; c, control; inf, infection; UA, ursolic acid; Con A, concanavalin A.

inflammatory mediators, and the important signal transducer, NO. As a model, M. tuberculosis H37Rv was used to sensitize RAW 264.7 cells and A549 cells, and Con A-stimulated rat splenocytes.
The present study focused on the expression of $C O X-2$ and $i N O S$, as they are usually induced during inflammatory conditions, and are reduced by the effect of flavonoids $(35,36)$. Abnormal upregulation of COX-2 and/or iNOS may be 
associated with certain types of cancer or inflammatory disorders $(37,38)$. In the present study, infection by $M$. tuberculosis H37Rv or treatment with Con A significantly increased the mRNA levels of $C O X-2$ and/or $i N O S$, which were downregulated by UA. NO, the product of iNOS, is crucial during inflammation. In addition to downregulating the expression levels of $C O X-2$ and $i N O S$, UA decreased the release of NO, which was induced following mycobacterial infection, in the cell culture medium. The infected A549 cells exhibited delayed NO release, compared with the RAW 264.7 cells. It has been reported that mycobacterial antigenic components produce significantly higher levels of NO at $48 \mathrm{~h}$ in A549 cells (39).

To detect anti-inflammatory activity, the present study examined the ability of UA to reduce the production of $T N F-\alpha$ in the mycobacteria-infected RAW 267.4 and A549 cells, and Con A-stimulated rat splenocytes. $T N F-\alpha$ is pivotal in inflammation, and its effect on the reduction of $I L-1 \beta$ and $I L-6$ were examined in similar treatment conditions. All three cytokines were upregulated when stimulated by M. tuberculosis H37Rv in the RAW 267.4 cells, A549 cells and Con A-stimulated rat splenocytes. The three cytokines were induced by different stimuli in different cells, however, UA significantly reduced their expression levels at the transcriptional level in the present study. Upon stimulation, the expression levels of various cytokines, inflammatory mediators, including $i N O S$ and $C O X-2$, and NO release were induced at varying magnitudes and at different times.

UA induced marked inhibitory effects on the expression levels of cytokines and immunomodulatory mediators, and on NO release. These findings, and the results of previous reports suggest that UA has significant potential in mitigating the induced inflammatory response. Further detailed investigations of UA are required, to determine its potential as a functional remedy to control inflammation in various diseases.

\section{Acknowledgements}

This study was supported by a Grant from the Ministry of Health \& Welfare R\&D Project, Republic of Korea (grant no. HI13C0828).

\section{References}

1. Coussens LM and Werb Z: Inflammation and cancer. Nature 420: 860-867, 2002.

2. Checker R, Sandur SK, Sharma D, Patwardhan RS, Jayakumar S, Kohli V, Sethi G, Aggarwal BB and Sainis KB: Potent anti-inflammatory activity of ursolic acid, a triterpenoid antioxidant, is mediated through suppression of NF-kB, AP-1 and NF-AT. PLoS One 7: e31318, 2012.

3. Dalgleish AG and O'Byrne KJ: Chronic immune activation and inflammation in the pathogenesis of AIDS and cancer. Adv Cancer Res 84: 231-276, 2002.

4. Kaser A, Zeissig S and Blumberg RS: Inflammatory bowel disease. Annu Rev Immunol 28: 573-621, 2010.

5. Ishiguro Y: Mucosal proinflammatory cytokine production correlates with endoscopic activity of ulcerative colitis. J Gastroenterol 34: 66-74, 1999.

6. Scott DL, Wolfe F and Huizinga TW: Rheumatoid arthritis. Lancet 376: 1094-1108, 2010.

7. Lee YJ, Han SB, Nam SY, Oh KW and Hong JT: Inflammation and alzheimer's disease. Arch Pharm Res 33: 1539-1556, 2010 .
8. Achoui M, Appleton D, Abdulla MA, Awang K, Mohd MA and Mustafa MR: In vitro and in vivo anti-inflammatory activity of 17-O acetylacuminolide through the inhibition of cytokines, NF-kB translocation and IKK $\beta$ activity. PLoS One 5: e15105, 2010.

9. Zumla A, Rao M, Parida SK, Keshavjee S, Cassell G, Wallis R, Axelsson-Robertsson R, Doherty M, ersson J and Maeurer M: Inflammation and tuberculosis: Host-directed therapies. J Intern Med 277: 373-387, 2014.

10. Ellner JJ: Review: The immune response in tuberculosis implication for tuberculosis control. J Infect Dis 176: 1351-1359, 1997.

11. Fenton MJ and Vermeulen MW: Immunopathology of tuberculosis: Roles of macrophages and monocytes. Infect Immun 64: 683-690, 1996

12. Rich EA, Torres M, Sada E, Finegan CK, Hamilton BD and Toossi Z: Mycobacterium tuberculosis (MTB)-stimulated production of nitric oxide by human alveolar macrophages and relationship of nitric oxide production to growth inhibition of MTB. Tubercle Lung Dis 78: 247-255, 1997.

13. Roy S, Sharma S, Sharma M, Aggarwal R and Bose M: Induction of nitric oxide release from the human alveolar epithelial cell line A549: An in vitro correlate of innate immune response to mycobacterium tuberculosis. Immunology 112: 471-480, 2004.

14. Celada A and Nathan C: Macrophage activation revisited. Immunol Today 15: 100-102, 1994.

15. Nathan CF and Hibbs JB Jr: Role of nitric oxide synthesis in macrophage antimicrobial activity. Curr Opin Immunol 3: 65-70, 1991.

16. Liu J: Pharmacology of oleanolic acid and ursolic acid. J Ethnopharmacol 49: 57-68, 1995.

17. Ikeda Y, Murakami A and Ohigashi H: Ursolic acid: An antiand proinflammatory triterpenoid. Mol Nutr Food Res 52: 26-42, 2008.

18. Tsai SJ and Yin MC: Antioxidative and anti-inflammatory protection of oleanolic acid and ursolic acid in PC12 cells. J Food Sci 73: H174-H178, 2008

19. Shishodia S, Majumdar S, Banerjee S and Aggarwal BB: Ursolic acid inhibits nuclear factor-kappaB activation induced by carcinogenic agents through suppression of IkappaBalpha kinase and p65 phosphorylation: Correlation with down-regulation of cyclooxygenase 2, matrix metalloproteinase 9 and cyclin D1. Cancer Res 63: 4375-4383, 2003.

20. Martin A, Camacho M, Portaels F and Palomino JC: Resazurin microtiter assay plate testing of mycobacterium tuberculosis susceptibilities to second-line drugs: Rapid, simple and inexpensive method. Antimicrob Agents Chemother 47: 3616-3619, 2003.

21. Diacon AH, Maritz JS, Venter A, van Helden PD, Andries K, McNeeley DF and Donald PR: Time to detection of the growth of mycobacterium tuberculosis in MGIT 960 for determining the early bactericidal activity of antituberculosis agents. Eur J Clin Microbiol Infect Dis 29: 1561-1565, 2010.

22. Zerin T, Lee M, Jang WS, Nam KW and Song HY: Ursolic acid reduces Mycobacterium tuberculosis-induced nitric oxide release in human alveolar A549 cells. Mol Cells 38: 610-615 2015.

23. Zerin T, Kim YS, Hong SY and Song HY: Protective effect of methylprednisolone on paraquat-induced A549 cell cytotoxicity via induction of efflux transporter, P-glycoprotein expression. Toxicol Lett 208: 101-107, 2012.

24. Lee HJ, Zerin T, Kim YH, Lee BE and Song HY: Immunomodulation potential of Artemisia capillaris extract in rat splenocytes. Intern J Phytomed 5: 356-361, 2013.

25. Wallace JL: Nitric oxide as a regulator of inflammatory processes. Mem Inst Oswaldo Cruz 100 (Suppl 1): S5-S9, 2005.

26. Medzhitov R: Origin and physiological roles of inflammation. Nature 454: 428-435, 2008.

27. Subbian S, Tsenova L, O'Brien P, Yang G, Koo MS, Peixoto B, Fallows D, Dartois V, Muller G and Kaplan G: Phosphodiesterase-4 inhibition alters gene expression and improves isoniazid-mediated clearance of mycobacterium tuberculosis in rabbit lungs. PLoS Pathog 7: e1002262, 2011.

28. Tobin DM, Roca FJ, Oh SF, McFarland R, Vickery TW, Ray JP, Ko DC, Zou Y, Bang ND, Chau TT, et al: Host genotype-specific therapies can optimize the inflammatory response to mycobacterial infections. Cell 148: 434-446, 2012.

29. Skerry C, Harper J, Klunk M, Bishai WR and Jain SK: Adjunctive TNF inhibition with standard treatment enhances bacterial clearance in a murine model of necrotic TB granulomas. PLoS One 7: e39680, 2012. 
30. Bermudez LE and Goodman J: Mycobacterium tuberculosis invades and replicates within type II alveolar cells. Infect Immun 64: 1400-1406, 1996.

31. Garcia-Perez BE, Mondragon-Flores R and Luna-Herrera J: Internalization of mycobacterium tuberculosis by macropinocytosis in non-phagocytic cells. Microb Pathog 35: 49-55, 2003.

32. Suh N, Honda T, Finlay HJ, Barchowsky A, Williams C, Benoit NE, Xie QW, Nathan C, Gribble GW and Sporn MB Novel triterpenoids suppress inducible nitric oxide synthase (iNOS) and inducible cyclooxygenase (COX-2) in mouse macrophages. Cancer Res 58: 717-723, 1998.

33. Ryu SY, Oak MH, Yoon SK, Cho DI, Yoo GS, Kim TS and Kim KM: Anti-allergic and anti-inflammatory triterpenes from the herb of Prunella vulgaris. Planta Med 66: 358-360, 2000

34. Checker R, Sandur SK, Sharma D, Patwardhan RS, Jayakumar S, Kohli V, Sethi G, Aggarwal BB and Sainis KB: Potent anti-inflammatory activity of ursolic acid, a triterpenoid antioxidant, is mediated through suppression of NF- $\kappa \mathrm{B}, \mathrm{AP}-1$ and NF-AT. PLoS One 7: e31318, 2012.
35. Moita E, Gil-Izquierdo A, Sousa C, Ferreres F, Silva LR, Valentão P, Domínguez-Perles R, Baenas $\mathrm{N}$ and Andrade PB: Integrated analysis of COX-2 and iNOS derived inflammatory mediators in LPS-stimulated RAW macrophages pre-exposed to Echium plantagineum L. bee pollen extract. PLoS One 8: e59131, 2013.

36. Kim JB, Han AR, Park EY, Kim JY, Cho W, Lee J, Seo EK and Lee KT: Inhibition of LPS-induced iNOS, COX-2 and cytokines expression by poncirin through the NF-kappaB inactivation in RAW 264.7 macrophage cells. Biol Pharm Bull 30: 2345-2351, 2007.

37. Weinberg JB: Nitric oxide synthase 2 and cyclooxygenase 2 interactions in inflammation. Immunol Res 22: 319-341, 2000.

38. Camuesco D, Comalada M, Rodríguez-Cabezas ME, Nieto A, Lorente MD, Concha A, Zarzuelo A and Gálvez J: The intestinal anti-inflammatory effect of quercitrin is associated with an inhibition in iNOS expression. Br J Pharmacol 143: 908-918, 2004.

39. Roy S, Sharma S, Sharma M, Aggarwal R and Bose M: Induction of nitric oxide release from the human alveolar epithelial cell line A549: An in vitro correlate of innate immune response to mycobacterium tuberculosis. Immunology 112: 471-480, 2004. 